\title{
Characteristic of isolated crude bromelain extract from cayenne pineapple crown in various drying temperature and its effect on meat texture
}

\author{
${ }^{1}$ Rizqiati, H., ${ }^{2}$ Nugraheni, A., ${ }^{1, *}$ Susanti, S., ${ }^{1}$ Fatmawati, L., ${ }^{2}$ Nuryanto, N. and ${ }^{3}$ Arifan, F. \\ ${ }^{I}$ Faculty of Animal and Agricultural Sciences, Diponegoro University, Indonesia. Jl. Prof. Soedarto, SH., \\ Tembalang, Semarang, Indonesia-50275 \\ ${ }^{2}$ Faculty of Medicine, Diponegoro University, Indonesia. Jl. Prof. Soedarto, SH., Tembalang, Semarang, \\ Indonesia-50275 \\ ${ }^{3}$ Vocational School, Diponegoro University, Indonesia. Jl. Prof. Soedarto, SH., Tembalang, Semarang,
} Indonesia-50275

\begin{abstract}
Article history:
January 2021

Accepted: 13 April 2021

Available Online: 10

September 2021

\section{Keywords:}

Bromelain enzyme,

Pineapple crown,

Temperature
\end{abstract}

Received: 30 December 2020

Received in revised form: 25

DOI:

https://doi.org/10.26656/fr.2017.5(5).692

\begin{abstract}
Bromelain enzyme is a protease enzyme that is abundantly found in pineapples. Pineapple crown is a part of pineapple that contains bromelain enzyme which its content remains unknown. This study was aimed to discover the effect of drying on the moisture content, yield, and characteristics of the enzyme of cayenne pineapple crown, namely protein content, activity units and specific activities. This study also aimed to discover its effect on the beef texture with a difference in duration in the immersion process. The method used was different drying temperatures of $55^{\circ} \mathrm{C}, 50^{\circ} \mathrm{C}, 45^{\circ} \mathrm{C}, 40^{\circ} \mathrm{C}, 35^{\circ} \mathrm{C}$, and $30^{\circ} \mathrm{C}$ which was analysed descriptively and the difference of immersion duration in beef using the Completely Randomized Design (CRD) method with four treatments, namely immersion duration of 0-hour, 2-hrs, 4-hrs, 6-hrs with 5 repetitions. The results obtained was the optimal drying temperature was $55^{\circ} \mathrm{C}$ due to its best moisture content, protein content, and best enzyme characteristics and it was known that there was a significant effect $(p<0.05)$ of immersion duration on the meat texture with the optimal immersion duration of $4 \mathrm{hrs}$ with the best texture.
\end{abstract}

\section{Introduction}

Pineapple cultivation is quite big in Indonesia because as tropical fruit, it becomes one of the promising export commodities. Pineapple production takes place in the fourth rank of the most produced commodity in Indonesia after banana, mango and orange with a total production of 1.8 million tons in 2018 (BPS, 2018). The varieties grown in Indonesia are very diverse, one of them is the cayenne pineapple variety because it is easy to cultivate. Along with an increase in pineapple production and export, it will be directly proportional to the increase of the waste produced. Fruit waste is an inedible part of the pineapple which are usually the skin, hump and pineapple crown (Wahyuni et al., 2016). Generally, pineapple wastes are still not optimally utilized, whereas it is well known that pineapple is a fruit that has rich bromelain enzyme content.

Bromelain enzyme is a protease enzyme functions to accelerate the simplification of protein compound elements using the hydrolysis process. Bromelain enzyme comes from a combination of protease enzyme which is mostly obtained from pineapples (Banerjee et al., 2018). The source of the bromelain enzyme comes from several utilized parts of pineapple such as the fruit (Kusuma et al., 2015), skin (Kumaunang and Kamu, 2011) and stem (Masri, 2013). Meanwhile, for the pineapple crown itself, there has not been much research conducted about its utilization. The enzyme is usually produced by extracting directly from fresh ingredients which makes it difficult to store in its raw form. The innovation conducted by drying the pineapple crowns into powder before taking the crude extract of the bromelain enzyme. In the drying process, it is necessary to pay attention to its optimal temperature so that it will not cause damage to the active substance in non-heat resistant raw materials that is possible to reduce the quality of the products produced (Widhyastini, 2013).

In the drying process to obtain powdered products, there are several things to consider such as the yield content produced and the moisture content of the product. Moisture content is a parameter of the product 
durability during the storage period and the durability of microorganism attacks (Zambrano et al., 2019). The yield resulted from the drying process of the pineapple crown is related to the level of effectiveness and economic value that it becomes one of the important parameters (Lekahena et al., 2014). The specific characteristics of crude enzymes can be discovered by conducting several tests, namely protein content, activity unit and enzyme-specific activity. The protein content is an illustration of enzyme content, activity unit as the amount of enzyme needed to hydrolyse protein in time units, and enzyme-specific activity shows the purity level of an enzyme (Atmaja, 2013). The application is conducted by testing the beef texture with the treatment of different immersion duration.

A previous study has been conducted by Nadzirah et al. (2016) about the application of bromelain powder produced from pineapple crowns in tenderizing the round cut of beef, but in this study, there is no further analysis regarding the characteristics of the bromelain enzyme, especially in the activity unit, enzyme-specific activity, and the raw material used, namely cayenne pineapple crown which is an Indonesian local fruit. This study is aimed to discover the drying effect on moisture content, yield, and characteristics of cayenne pineapple crown enzyme, namely protein content, activity unit and specific activities also to discover its effect on the texture of beef. The advantages of knowing the optimal drying temperature for the drying process of the cayenne pineapple crown based on parameters of moisture content, yield, and enzyme characteristics are protein content, activity unit and specific activity also to discover the optimal immersion duration of beef with texture parameters.

\section{Materials and methods}

\subsection{Materials}

The materials were used cayenne pineapple crown, distilled water, tissue, aluminium foil, muslin cloth, solution of sodium citrate buffer $\mathrm{pH} 6$ (Merck, Germany), BSA (Sigma-Aldrich, USA), Lowry reagent (Thermo, USA), foline solution (Merck, Germany), TCA 10\% (Merck, Germany), casein (Sigma-Aldrich, USA), standard bromelain enzyme (Life Extension, USA), phosphate buffer (Merck, Germany) and beef.

\subsection{Method}

The study was conducted with raw pineapple crowns dried at the temperatures used at $55^{\circ} \mathrm{C}, 50^{\circ} \mathrm{C}, 45^{\circ} \mathrm{C}, 40^{\circ} \mathrm{C}$, $35^{\circ} \mathrm{C}$, and $30^{\circ} \mathrm{C}$. The optimal temperature obtained was applied to beef with different in immersed duration of crude pineapple crown. Immersion was carried out to determine its effect on the texture of beef with CRD method in 4 treatment 5 replications obtained 20 experimental units. Immersion treatments were varied at $0 \mathrm{hr}$ (T1), 2 hrs (T2), 4 hrs (T3) and 6 hrs (T4).

\subsubsection{Preparation of pineapple crown powder}

The preparation of pineapple crown powders was carried adapted the method by Hanifah et al. (2017) with modifications. The pineapple crown of each variety was sorted to obtain the best result. Pineapple crowns were reduced in size by the cutting and grinding method. It was then arranged on a tray for drying in a cabinet dryer with a determined drying temperature difference of $55^{\circ} \mathrm{C}$, $50^{\circ} \mathrm{C}, 45^{\circ} \mathrm{C}, 40^{\circ} \mathrm{C}, 35^{\circ} \mathrm{C}$ and $30^{\circ} \mathrm{C}$ for $5 \mathrm{hrs}$. The dried pineapple crown was then ground with a grinder for 4 mins and sifted with 40 mesh.

\subsubsection{Process of bromelain enzyme extract isolation}

The process of isolated the crude bromelain enzyme extract of the pineapple crown was conducted by referred to Kumaunang and Kamu (2011) with modifications. Pineapple crown powder was weighed $20 \mathrm{~g}$ and dissolved with sodium citrate buffer solution $(\mathrm{pH} 7)$ then homogenized. The solution was then filtered with a muslin cloth and then centrifuged at 5,000 rpm for 15 mins, the supernatant from the centrifugation process was separated and stored at a temperature of $-25^{\circ} \mathrm{C}$.

\subsubsection{Moisture content}

The moisture content of pineapple crown powder adapted from the method of (AOAC, 2005) with modifications. The porcelain dish was dried at $105^{\circ} \mathrm{C}$ for $1 \mathrm{hr}$. Then, it was placed in the desiccator and weighed. The sample was weighed 3-5 g and placed in a dish. The sample was dried at $105^{\circ} \mathrm{C}$ for $3 \mathrm{hrs}$. The sample was then placed in a desiccator until it was cold and weighed again. Then, after weighing the dish, it was dried again in the oven until a constant weight was obtained. Determination of moisture content can be calculated according to Aguirre-Loredo et al. (2016).

\subsubsection{Yield}

The yield calculated for pineapple crown powder product was based on the ratio of the weight of the powder produced (final weight) to the initial weight expressed in per cent (\%). The yield was calculated with the according formula showed by Bhattacharjee et al. (2020).

\subsubsection{Protein content}

The procedure was tested for protein content according to Özel et al. (2010) with modifications. The protein content was determined by the Lowry method starting with a standard curve from the BSA standard 
solution of $1.00 \mathrm{mg} / \mathrm{mL}$ and reacted with the Lowry reagent then incubated for 10 mins. The combined solution was added with Folin-Ciocalteau reagent and incubated again for 30 mins. Next, the absorption was measured using a UV-Vis spectrophotometer at a wavelength of $650 \mathrm{~nm}$. The standard curve was made based on the determination of the wavelength from a solution with various concentrations with a range of 0.1 $\mathrm{mg} / \mathrm{mL}$. Furthermore, the protein content of the sample was tested by reacting it with $0.5 \mathrm{~mL}$ of the enzyme supernatant with Lowry-Folin reagent and measured at a wavelength of $650 \mathrm{~nm}$.

\subsubsection{Enzyme activity unit}

The bromelain enzyme activity unit was tested in crude extract adapted from Soares et al. (2012) with modifications. $0.5 \%$ casein as a substrate was added as much as $0.5 \mathrm{~mL}$ into the pineapple crown bromelain enzyme crude extract of $0.5 \mathrm{~mL}$ which was diluted 15 times. The phosphate buffer solution was added and incubated in a $37^{\circ} \mathrm{C}$ water bath for 20 mins. Then, $10 \%$ TCA was added and incubated for $10 \mathrm{mins}$ at room temperature. Centrifuge the solution for $4000 \mathrm{rpm}$ for 20 mins. The absorbance of the supernatant was read at a wavelength of $280 \mathrm{~nm}$ using UV-vis spectrophotometry.

\subsubsection{Enzyme specific activity}

Enzyme specific activity was calculated adapted the method from Kusuma et al. (2015). The specific activity was obtained from the result of the unit of enzyme activity divided by the protein content of the enzyme.

\subsubsection{Meat texture}

The texture of the meat was tested used a texture analyzer adapted Dalvi-Isfahan et al. (2016). The meat sample was placed right under the cylindrical meat probe. The center of the sample was then pressed and a number is printed on the equipment, beef tenderness was an observed parameter.

\subsection{Data analysis}

The data analysis for the parameters of moisture content, yield, enzyme characteristics including protein content, activity units and enzyme-specific activity were analysed descriptively. The data of beef texture was analysed using the analysis of variance (ANOVA) test. Parametric testing was conducted using the SPSS 26.0 application at a significance level of $<0.05$ and the test was continued with Duncan Multiple Range Test (DMRT) to find the mean value of the differences.

\section{Results and discussion}

\subsection{Moisture content}

The moisture content of pineapple crown powder ranged from $6.954 \%$ to $-7.285 \%$ (Table 1 ). The moisture content difference contained in pineapple crown powder is caused by the differences in the drying temperature which is conducted at $55^{\circ} \mathrm{C}$ that has the moisture content of $6.954 \%$ while at the temperature of $30^{\circ} \mathrm{C}$, it has a moisture content of $7.285 \%$. The increasing temperature will cause faster evaporation and transfer of moisture content that moisture content is reduced. The increase of temperature and drying time will cause various water molecules to evaporate which causes a decrease in the moisture content of pineapple crown powder (Ikhsan et al., 2016). The higher the drying air temperature produced, the faster the heat transfer and the faster the evaporation process of water from the material (Dewi and Satibi, 2015). A pineapple crown powder which has a low moisture content will make it easier in its usage, which is more practical and effective due to its ability to shorten the enzyme production process that is usually directly from fresh material and has a long shelf life because it is free from microbes and fungi. Low moisture content causes longer microbial growth because a moisture content that is less than $14 \%$ can prevent mould growth and will extend the shelf life of food (Lisa et al., 2015)

Table 1. Moisture content and yield of pineapple crown powder

\begin{tabular}{ccc}
\hline Drying Temperature & Moisture (\%) & Yield (\%) \\
\hline $55^{\circ} \mathrm{C}$ & 6.95 & 10.00 \\
$50^{\circ} \mathrm{C}$ & 6.98 & 9.80 \\
$45^{\circ} \mathrm{C}$ & 6.95 & 8.50 \\
$40^{\circ} \mathrm{C}$ & 6.95 & 9.00 \\
$35^{\circ} \mathrm{C}$ & 7.00 & 13.06 \\
$30^{\circ} \mathrm{C}$ & 7.28 & 13.43 \\
\hline
\end{tabular}

\subsection{Yield}

In this study, the yield is the ratio of the pineapple crown powder to the wet pineapple crown weight. The highest yield resulted from the drying temperature of $30^{\circ} \mathrm{C}(13.43 \%)$ while the range temperature of $40-55^{\circ} \mathrm{C}$ resulted in a lower yield (9.32\%). Based on the yield resulting from the drying process with different levels of temperature, the best temperature for the drying process to produce pineapple crown powder was $55^{\circ} \mathrm{C}$. This temperature is ideal for the drying process because obtain a high yield and is low in moisture (Table 1). The quality of the dried product is determined by yield and moisture content (Martinus, 2012). In this case, moisture content was affected by drying temperature also play a role in the final yield. The moisture content of the 
material contributed to its weight (Hatfield and Prueger, 2015).

\subsection{Protein content}

The protein content in the crude pineapple crown extract can represent the amount of enzyme content contained in the crude pineapple crown. Based on the data in Figure 1. It is known that the drying temperature changes used may not affect the protein content in the crude extract of pineapple crown because there is no significant decrease in the protein content. The range of protein produced from the pineapple crown ranging from $6.845-6.148 \mathrm{mg} / \mathrm{mL}$, which the highest protein content obtained was the cayenne pineapple variety with a drying temperature at $55^{\circ} \mathrm{C}$. The activity of the bromelain enzyme is generally the most optimum at $55^{\circ} \mathrm{C}$ (Ketnawa et al., 2010). At this temperature, each pineapple variety has a high protein content value that indicates a high enzyme activity value. The reaction that occurs in the enzyme will increase with the speed of the reaction but has certain limits until it reaches the denaturation temperature (Wardhani et al., 2016). Protein denaturation will cause a decrease in enzyme activity due to conformation changes. In terms of, unsuitable heating will also obtain transformation in the structure and original properties of the protein (Zhang and Romero, 2020). The drying temperature used for each enzyme production is different, however, the bromelain enzyme can work optimally at a temperature of $55^{\circ} \mathrm{C}$. When the temperature is very high the enzymes can be damaged.

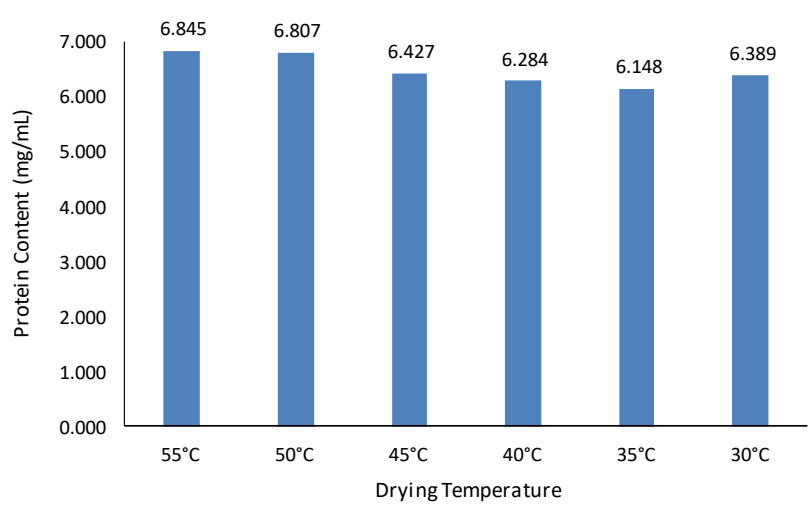

Figure 1. Protein content of crude extract pineapple crown

\subsection{Enzyme activity unit}

The enzyme activity unit is the number of enzymes that can be obtained in the transformation or changes of one substrate molecule per min in optimal measurement conditions (Djarkasi et al., 2017). At temperature $55^{\circ} \mathrm{C}$, the enzyme activity unit value was $1.964 \mathrm{U} / \mathrm{mL}$, it did not decrease at $50^{\circ} \mathrm{C}$ drying temperature, but at $45^{\circ} \mathrm{C}$ it decreases to $1.63 \mathrm{U} / \mathrm{mL}$ (Figure 2). The changes in drying temperature in the $10^{\circ} \mathrm{C}$ range will cause a change in the value of the bromelain enzyme activity unit, while the $5^{\circ} \mathrm{C}$ temperature range does not give a significant change in the value of the enzyme activity unit. Enzyme activity will increase until the optimal temperature is reached, but will extremely decrease if the temperature used exceeds the optimal value due to the enzyme damage (enzyme inactivation) or modification of the protein (Han et al., 2016).

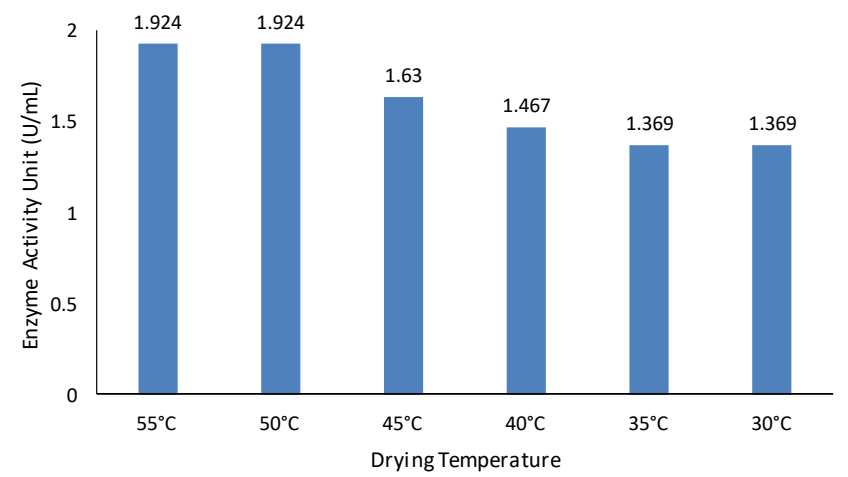

Figure 2. Enzyme activity unit of crude extract pineapple crown

\subsection{Enzyme specific activity}

The specific activity can be interpreted as a unit of enzyme activity in every milligram of protein contained inside the enzyme crude extract (Putri et al., 2013). Enzyme specific activity is one of the indicators to measure the purity of an enzyme (Feng et al., 2017). The value of specific enzyme activity in crude pineapple crown extract ranges between $0.283-0.214 \mathrm{U} / \mathrm{mg}$ (Figure. 3), shows a decrease that is in line with the value in protein content and the unit activity of the enzyme. The specific enzyme activity also showed a decrease with increasing the drying temperature. The specific activity of the enzyme is related to the formation of lipids in the presence of temperature during the process (Zhang et al., 2020). In general, every enzyme has a different optimum temperature to carry out its function. Bromelain enzyme will be active in rank temperature from 50 to $55^{\circ} \mathrm{C}$. The rate of activity of the bromelain enzyme will increase along with temperature rise until its optimal limit. If the temperature exceeds the

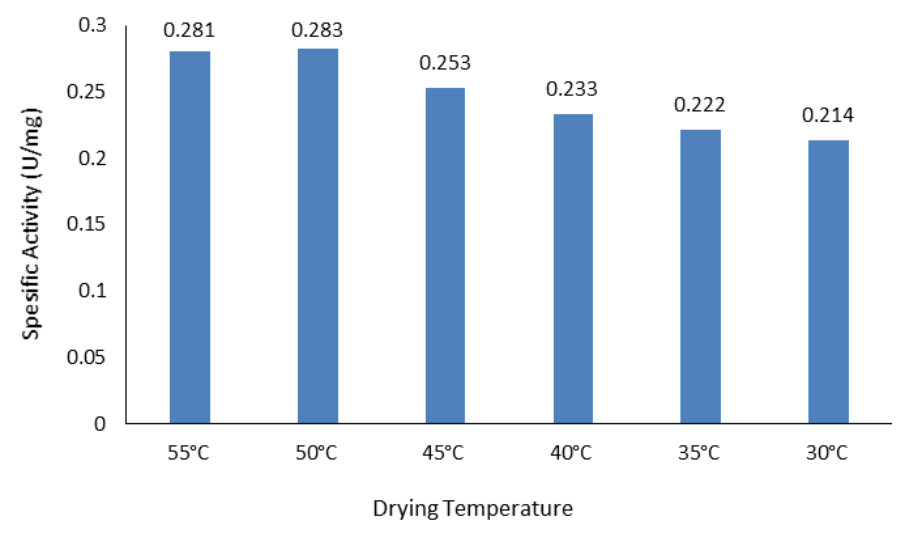

Figure 3. Bromelain enzyme specific activity of crude extract pineapple crown

(C) 2021 The Authors. Published by Rynnye Lyan Resources 
optimal limit, it will cause enzyme denaturation and disrupt the active side of enzyme-substrate interaction (Nurhidayat et al., 2018).

Table 2. Beef texture immersed in the solution of bromelain crude extract isolated from pineapple crown solution

\begin{tabular}{cc}
\hline Immersion Duration (hour) & Tenderness \\
\hline 0 & $5,540.17 \pm 767.48^{\mathrm{a}}$ \\
2 & $4,067.15 \pm 510.46^{\mathrm{ab}}$ \\
4 & $1,766.81 \pm 402.22^{\mathrm{c}}$ \\
6 & $3,090.72 \pm 348.12^{\mathrm{bc}}$ \\
\hline
\end{tabular}

Values are presented as mean \pm SE. Values with different superscript within the same column are significantly different $(\mathrm{p}<0.05)$.

\subsection{Texture}

A texture test on the beef sample was carried out by using the crude extract that had been dried at $55^{\circ} \mathrm{C}$ because it has the most optimal bromelain enzyme characteristic. Based on Table 2 treatment of immersion beef in crude pineapple extract with different immersion duration used gives a significant effect on the quality of the meat texture $(p<0.05)$. Immersing the meat inside the solution of crude pineapple crown extract is one of the techniques to tenderize meat, where the longer the optimal immersion duration used will cause the meat to become more tender. The duration of treatment used for immersion of the meat is 2 to $6 \mathrm{hrs}$ with T1 (control or fresh meat). Bromelain enzyme is a potential proteolytic enzyme that can tenderize meat because it has a softening effect on the myosin and myofibrillar protein in the meat (Arshad et al., 2014). The best meat texture is the immersion duration for $4 \mathrm{hrs}$ because the immersion duration for $6 \mathrm{hrs}$ shows an increase in texture due to the clumping of meat during the storage process in the refrigerator. The texture of meat that becomes tender is also influenced by the protein denaturation that is hydrolysed by the bromelain enzyme, which is a proteolytic enzyme that the meat will loosen and becomes more tender (Paramartha et al., 2019).

\section{Conclusion}

Based on the result obtained, drying the pineapple crown does not damage the bromelain enzyme content if it is carried out at the optimal temperature. Drying the pineapple crown powder will also give the advantage of being able to store it longer. The application of bromelain enzyme from the crude pineapple crown cayenne variety can be used as a meat softener. The $55^{\circ} \mathrm{C}$ drying temperature has the best enzyme characteristics as well as low moisture content and high yield produced, meanwhile the best tenderness texture occurs when the immersion duration of the beef is $4 \mathrm{hrs}$.

\section{References}

Aguirre-Loredo, R.Y., Rodríguez-Hernández, A.I., Morales-Sánchez, E., Gómez-Aldapa, C.A. and Velazquez, G. (2016). Effect of equilibrium moisture content on barrier, mechanical and thermal properties of chitosan films. Food Chemistry, 196, 560-566.

j.foodchem.2015.09.065

Arshad, Z.I.M., Amid, A., Yusof, F., Jaswir, I., Ahmad, K. and Loke, S.P. (2014). Bromelain: an overview of industrial application and purification strategies. Applied Microbiology and Biotechnology. 98(17), 7283-7297. https://doi.org/10.1007/s00253014-5889-y

AOAC (Association of Official Analytical Chemists). (2005). Official Methods of Analysis of AOAC. $18^{\text {th }}$ ed. Maryland USA: AOAC International.

Atmaja, D.S. (2013). Isolation, purification and characterization of $\alpha$-amylase from Trichoderma viride FNCC 6013. Chem Info Journal, 1(1), 85-93.

BPS (Badan Pusat Statistik). (2018). Statistik Tanaman Buah-buahan dan Sayuran Tahunan Indonesia. Jakarta: Badan Pusat Statistik Indonesia. [In Bahasa Indonesia].

Banerjee, S., Ranganathan, V., Patti, A. and Arora, A. (2018). Valorisation of pineapple wastes for food and therapeutic applications. Trends in Food Science and Technology, 82(1), 60-70. https:// doi.org/10.1016/j.tifs.2018.09.024

Bhattacharjee, S., Haldar, D., Manna, M.S., Gayen, K. and Bhowmick, T.K. (2020). A sustainable approach to enhance fruit shelf-life: Edible coating from pineapple fruit waste biomass. Journal of Applied Polymer Science, 138(15), 1-17. https:// doi.org/10.1002/app.50388

Dalvi-Isfahan, M., Hamdami, N. and Le-Bail, A. (2016). Effect of freezing under electrostatic field on the quality of lamb meat. Innovative Food Science and Emerging Technologies, 37(Part A), 68-73. https:// doi.org/10.1016/j.ifset.2016.07.028

Dewi, A.K. and Satibi, L. (2015). Kajian pengaruh temperatur pengeringan semprot (Spray dryer) terhadap waktu pengeringan dan rendemen bubuk santan kelapa (Coconut milk powder). Jurnal Konversi, 4(1), 25-31. [In Bahasa Indonesia].

Djarkasi, G.S., Raharjo, S. and Noor, Z. (2017). Isolasi dan akitivitas spesifik enzim lipase indigenous biji kenari. Agricultural Technology Journal, 8(1), 2835. [In Bahasa Indonesia].

Feng, J., Liu, H., Yang, X., Gao, A., Liao, J., Feng, L., $\mathrm{Pu}$, J., Xie, Y., Long, G. and Liao, F. (2013). Comparison of activity indexes for recognizing 
enzyme mutants of higher activity with uricase as model. Chemistry Central Journal, 7(1), 1-8. https:// doi.org/10.1186/1752-153X-7-69

Han, F., Pei, H., Hu, W., Han, L., Zhang, S. and Ma, G. (2016). Effect of high-temperature stress on microalgae at the end of the logarithmic phase for the efficient production of lipid. Environmental Technology, 37(20), 2649-2657. https:// doi.org/10.1080/09593330.2016.1158867

Hanifah, R.N., Al-Baarri, A.N.M. and Pramono, Y.B. (2017). Determinasi kadar randemen, tampilan warna, dan imaginery bubuk cincau hijau (Premna oblongifolia) dengan suhu pengeringan yang berbeda. Jurnal Teknologi Pangan, 1(1), 25-27. [In Bahasa Indonesia].

Hatfield, J.L. and Prueger, J.H. (2015). Temperature extremes: Effect on plant growth and development Weather and Climate Extremes, 10(Part A), 4-10. https://doi.org/10.1016/j.wace.2015.08.001

Ikhsan, M., Muhsin, M. and Patang, P. (2018). Pengaruh variasi suhu pengering terhadap mutu dendeng ikan lele dumbo (Clarias gariepinus). Jurnal Pendidikan Teknologi Pertanian, 2(2), 114-122. https:// doi.org/10.26858/jptp.v2i2.5166 [In Bahasa Indonesia].

Ketnawa, S., Rawdkuen, S. and Chaiwut, P. (2010). Two phase partitioning and collagen hydrolysis of bromelain from pineapple peel Nang Lae cultivar. Biochemical Engineering Journal, 52(2-3), 205-211. https://doi.org/10.1016/j.bej.2010.08.012

Kumaunang, M. and Kamu, V. (2011). Aktivitas enzim bromelin dari ekstrak kulit nenas (Anenas comosus). Jurnal Ilmiah Sains, 11(2), 198201. https://doi.org/10.35799/jis.11.2.2011.207 [In Bahasa Indonesia].

Kusuma, I.P., Laksmiwati, A.A.I.A.M., Arsa, M. and Ratnayani, K. (2015). Perbandingan aktivitas spesifik ekstrak kasar enzim bromelin buah nanas yang diisolasi dengan beberapa jenis garam pengendap. Journal of Chemistry, 9(2), 139-146. [In Bahasa Indonesia].

Lekahena, V., Faridah, D.N., Syarief, R. and Peranginangin, R. (2014). Physicochemical characterization of nano calcium from tilapia bone extracted by alkaline and acid solution. Jurnal Teknologi dan Industri Pangan, 25(1), 57-64. https:// doi.org/10.6066/jtip.2014.25.1.57

Lisa, M., Lutfi, M. and Susilo, B. (2015). Pengaruh suhu dan lama pengeringan terhadap mutu tepung jamur tiram putih (Plaerotus ostreatus). Jurnal Keteknikan Pertanian Tropis dan Biosistem, 3(3), 270-279. [In Bahasa Indonesia].
Martunis, M. (2012). Effect of drying temperature and time to quantity and quality of potato starch variety of granola. Jurnal Teknologi dan Industri Pertanian Indonesia, 4(3), 26-30.

Masri, M. (2013). Isolation and measuring the enzyme activity of crude extract of bromelin stems pineapple (Ananas comosus) on the variation of $\mathrm{pH}$. BIOSEL (Biology Science and Education), 2(2), 80-92.

Nadzirah, K.Z., Zainal, S., Noriham, A. and Normah, I. (2016). Application of bromelain powder produced from pineapple crowns in tenderising beef round cuts. Journal of International Food Research Journal, 23(4), 1590-1599.

Nurhidayat, I., Setiasih, S., Handayani, S. and Hudiyono, S. (2018). Kinetic studies of bromelain purified from Palembang pineapple (Ananas comosus [L.] Merr) using gel filtration chromatography and its activity as antiplatelet aggregation. AIP Conference Proceedings, 2023, $020068 . \quad \mathrm{https}: / /$ doi.org/10.1063/1.5064065

Özel, A., Colak, A., Arslan, O. and Yildirim, M. (2010). Purification and characterisation of a polyphenol oxidase from Boletus erythropus and investigation of its catalytic efficiency in selected organic solvents. Food Chemistry, 119(3), 1044-1049. https://doi.org/10.1016/j.foodchem.2009.08.011

Paramartha, D.N.A., Sulastri, Y., Widyasari, R. and Zainuri, Z. (2019). Formulasi daging keong sawah dan tepung porang terhadap mutu fisik dan sensoris bakso. Journal Pro Food, 5(2), 549-559. https:// doi.org/10.29303/profood.v5i2.130 [In Bahasa Indonesia].

Putri, R.A., Kusrijadi, A. and Suryatna, A. (2013). Kajian penggunaan amonium sulfat pada pengendapan enzim protease (papain) dari buah pepaya sebagai koagulan dalam produksi keju cottage. Jurnal Sains dan Teknologi Kimia, 4(2), 159 -168. [In Bahasa Indonesia].

Soares, P.A.G., Vaz, A.F.M. Vaz, Correi, M.T.S. Correi, Pessoa Jr., A. and Carneiro-da-Cunha, M.G. (2012). Purification of bromelain from pineapple wastes by ethanol precipitation. Separation and Purification Technology, 98(1), 389-395. https://doi.org/10.1016/ j.seppur.2012.06.042

Wahyuni, S.A., Kadarusno, A.H. and Suwerda, B. (2016). Pemanfaatan Saccharomyces cereviceae dan limbah buah nanas pasar beringharjo yogyakarta untuk pembuatan bioetanol. Sanitasi: Jurnal Kesehatan Lingkungan, 7(4), 151-159. https:// doi.org/10.29238/sanitasi.v7i4.46 [In Bahasa Indonesia].

Wardhani, D.H., Aryanti, N., Murvianto, F. and 
Yogananda, K.D. (2016). Peningkatan kualitas glukomanan dari amorphophallus oncophyllus secara enzimatis dengan a-amilase. Jurnal Inovasi Teknik Kimia, 1(2), 71-77. [In Bahasa Indonesia].

Widhyastini, I.M. (2017). The effect of drying on the outer and inner skin of mangosteen (Gracinia mangostana, L.) for the content of proximate analysis, alkaloid and flavanoid. Journal of Sains Natural, 3(2), 193-200. https://doi.org/10.31938/ jsn.v3i2.69

Zambrano, M.V., Dutta, B., Mercer, D.G., MacLean, H.L. and Touchie, M.F. (2019). Assessment of moisture content measurement methods of dried food products in small-scale operations in developing countries: A review. Trends in Food Science and Technology, 88, 484-496. https:// doi.org/10.1016/j.tifs.2019.04.006

Zhang, Y. and Romero, H.M. (2020). Exploring the structure-function relationship of Great Northern and navy bean (Phaseolus vulgaris L.) protein hydrolysates: A study on the effect of enzymatic hydrolysis. International Journal of Biological Macromolecules, 162(1), 1516-1525. https:// doi.org/10.1016/j.ijbiomac.2020.08.019 